\title{
Endothelial dysfunction in adipose triglyceride lipase deficiency: role of perivascular adipose tissue
}

\author{
Marion Mussbacher ${ }^{1 *}$, Karoline Pail ${ }^{1}$, Gerald Wölkart ${ }^{1}$, Günter Hämmerle², Alois Lametschwandtner ${ }^{3}$, \\ Rudolf Zechner ${ }^{2}$, Bernd Mayer ${ }^{1}$, Astrid Schrammel ${ }^{1}$ \\ From 6th International Conference on CGMP: Generators, Effectors and Therapeutic Implications \\ Erfurt, Germany. 28-30 June 2013
}

\section{Background}

Perivascular adipose tissue (PVAT) has been shown to be an important modulator of vascular function through release of both relaxing and contracting factors. However, the involvement of PVAT in development of endothelial dysfunction is not well understood, yet. We have recently demonstrated that mice lacking adipose triglyceride lipase
(ATGL) suffer from severe endothelial dysfunction. Since vessels of these mice are coated with large amounts of PVAT, we speculated that this might potentially contribute to disturbed vascular homeostasis. Therefore, PVAT of wild type (WT) and ATGL knockout mice was characteri-zed in terms of inflammatory as well as oxidative stress. Additionally, we wanted to distinguish between
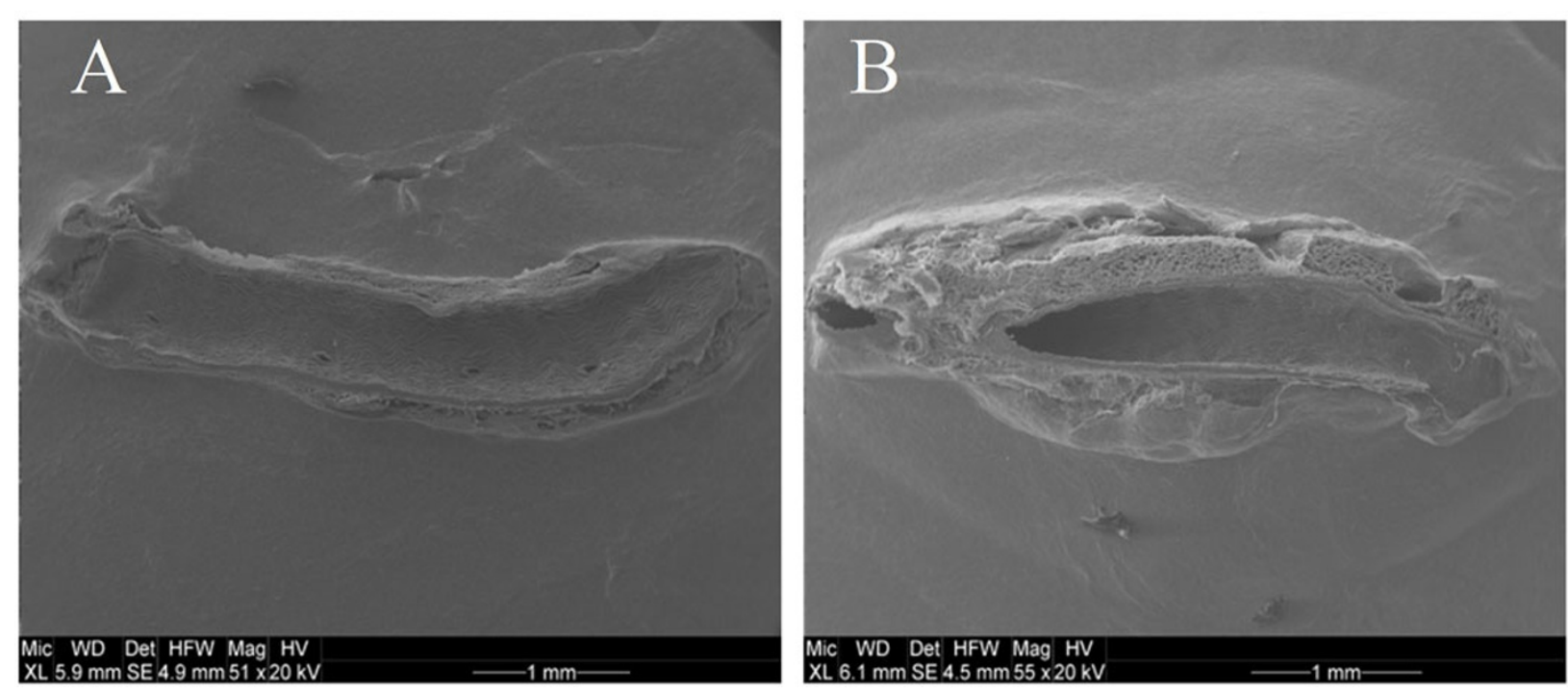

Figure 1 Thoracic aortas of WT (A) and ATGL(-/-) (B) mice were fixated by perfusion with glutaraldehyde in situ and analyzed by electron scanning microscopy.

\footnotetext{
* Correspondence: marion.mussbacher@uni-graz.at

'Department of Pharmacology and Toxicology, Institute of Pharmaceutical

Sciences, University of Graz, 8010 Graz, Austria

Full list of author information is available at the end of the article
}

(c) 2013 Mussbacher et al; licensee BioMed Central Ltd. This is an Open Access article distributed under the terms of the Creative 
short-term PVAT-mediated effects on vascular function as well as long-term in vivo interference of PVAT with aortic $\mathrm{NO} / \mathrm{cGMP}$ signaling.

\section{Results}

Knockout of ATGL resulted in 7-fold increase in PVAT wet weight. Adipose mRNA levels of the inflammation markers tumor necrosis factor $\alpha$ (TNF $\alpha$, monocyte chemoattractant protein 1 (MCP-1) and interleukin 6 (IL-6) were significantly increased in ATGL-deficient PVAT. In addition, NADPH oxidase isoform NOX2 as well as its cytosolic subunit p67phox were significantly upregulated at both mRNA and protein level, indicating the presence of oxidative stress. Massive infiltration of macrophages was confirmed by a tremendous increase of galectin-3 (Mac-2) protein expression. Performing isometric tension vasomotor studies, we found that PVAT did not affect aortic relaxation to the endothelium-dependent agonist acetylcholine or to the NO donor 2,2-diethyl1-nitroso-oxyhydrazine (DEA/NO) in WT and ATGL knockout mice. By contrast, presence of PVAT reduced the contractile efficiency of the thromboxane mimetic 9,11-dideoxy-11 $\alpha, 9 \alpha$-epoxy-methanoprostaglandin $\mathrm{F} \alpha$ (U46619) in WT aortas (from $155.1 \pm 5.7 \%$ to 125.6 $\pm 9.4 \%)$. This effect was even more pronounced in ATGL-deficient aortas (162.9 $\pm 5.5 \%$ to $90.4 \pm 9.6 \%)$, suggesting presence of a PVAT-derived relaxing factor.

\section{Conclusion}

These data suggest that PVAT-derived inflammatory and oxidative stress might contribute to endothelial dysfunction in ATGL deficiency. Further studies are necessary to identify the PVAT-derived relaxing factor and its role in endothelial (dys)function. To address in vivo functional consequences of PVAT on vascular function, a mouse model of adipose tissue-specific rescue of ATGL is currently created.

\section{Authors' details}

'Department of Pharmacology and Toxicology, Institute of Pharmaceutical Sciences, University of Graz, 8010 Graz, Austria. ${ }^{2}$ Department of Molecular Bioscience, University of Graz, 8010 Graz, Austria. ${ }^{3}$ Department of Cell Biology and Physiology, Vessel and Muscle Research Unit, University of Salzburg, 5020 Salzburg, Austria.

Published: 29 August 2013

doi:10.1186/2050-6511-14-S1-P45

Cite this article as: Mussbacher et al:: Endothelial dysfunction in adipose triglyceride lipase deficiency: role of perivascular adipose tissue. BMC Pharmacology and Toxicology 2013 14(Suppl 1):P45.
Submit your next manuscript to BioMed Central and take full advantage of:

- Convenient online submission

- Thorough peer review

- No space constraints or color figure charges

- Immediate publication on acceptance

- Inclusion in PubMed, CAS, Scopus and Google Scholar

- Research which is freely available for redistribution

Submit your manuscript at www.biomedcentral.com/submit 